ارزيابى جندمعياره قابليت اراضى براى كشت ديم (مطالعه موردى: زيرحوضه آبخيز پِلاسجان)

وحيد راهدارى '، عليرضا سفيانيان'، سعيد يورمنافى '، حميد قيومى محمدى"؛

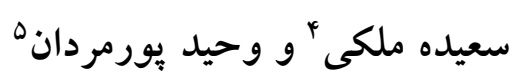

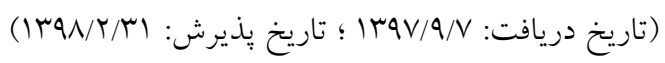

جكيده

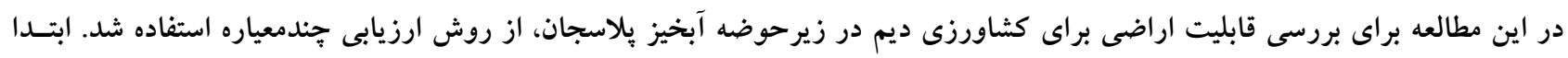

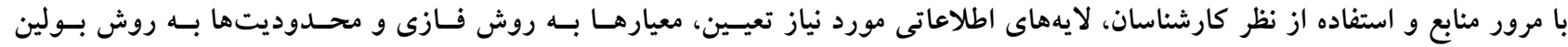

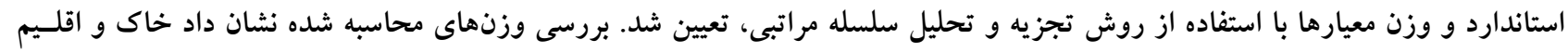

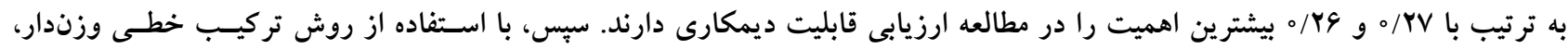

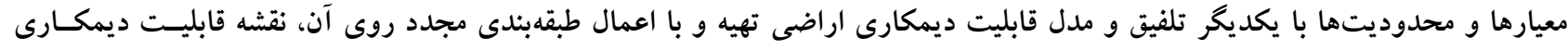

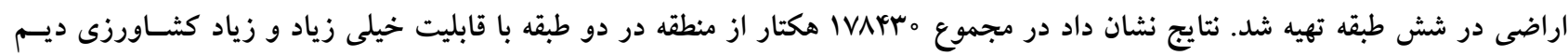

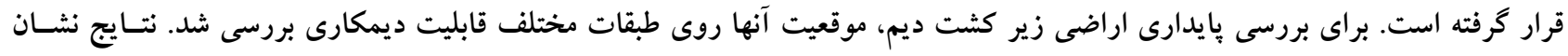

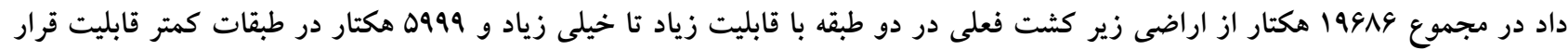
كر فتهاند.

وازههاى كليدى: ديمكارى، قابليت اراضى، خاك، آب، تركيب خطى وزندار، پِلاسجان

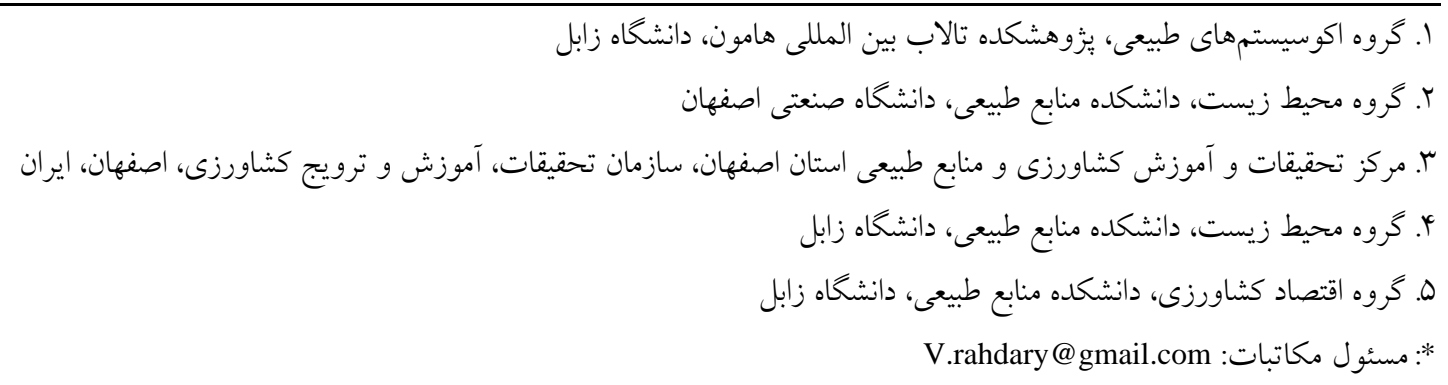


آب، سرمايه و ايجاد اشتغال و درآمدزايى براى كشاورزان، بدون

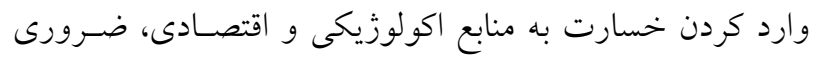

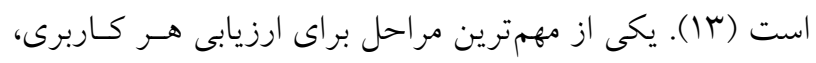

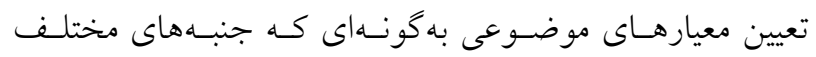

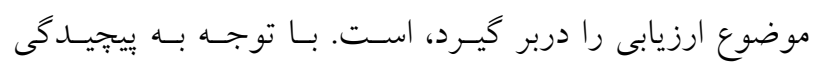

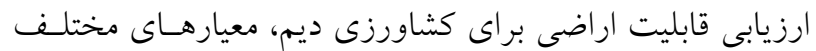

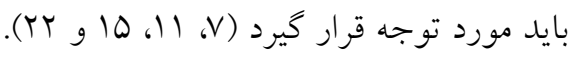

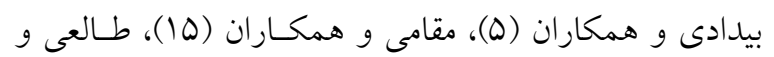

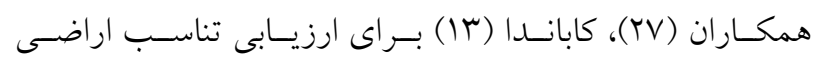

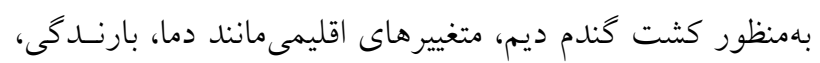

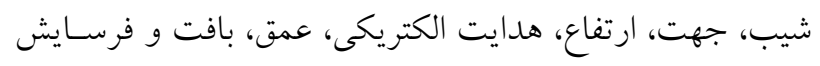

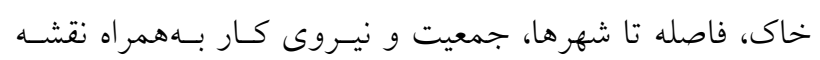
كاربرى و يوشش اراضى را وارد مدل كردهاند. روش تركيب خطى وزندار (Weighted linear combination)

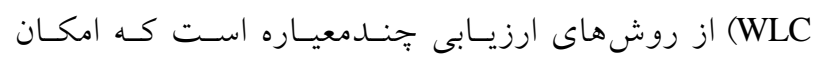

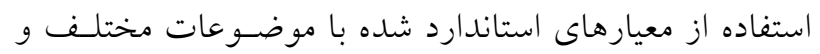

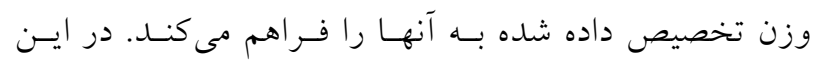

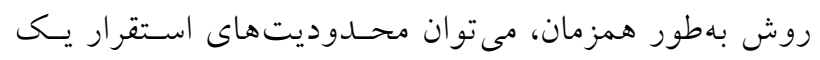

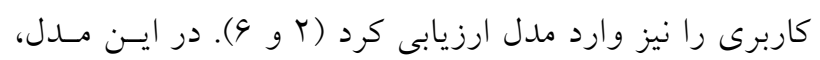

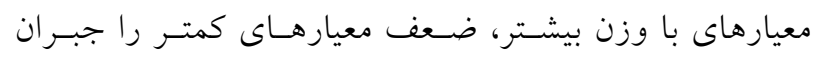

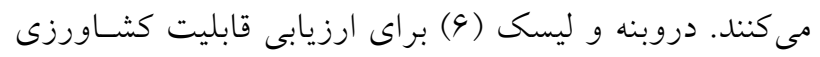

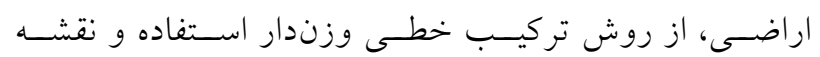

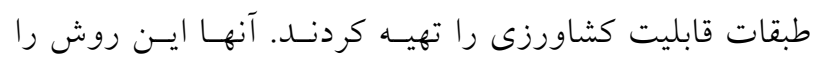

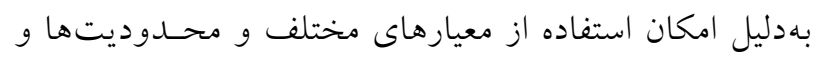

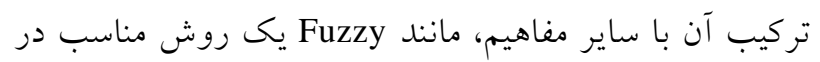
ارزيابى هاى جندمعياره، بيان كردهاند.

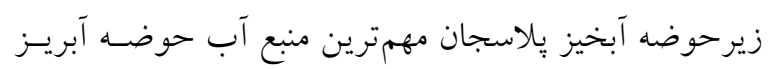
كاو خونى است كه در طى دو دهه اخير، اراضى كشاورزى ديم

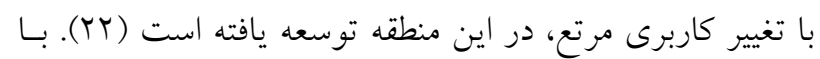

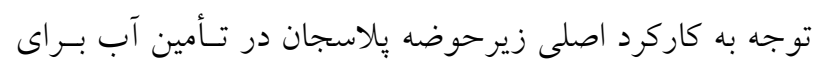

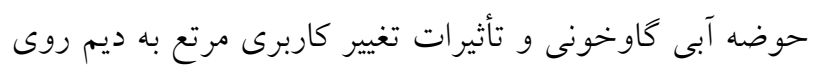

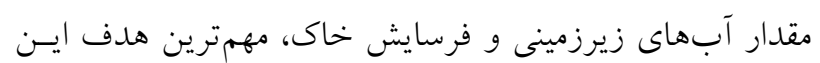

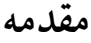

ديمكارى بهمعنى كشت بدون آبيارى است و بـه زراعتى كفتـه

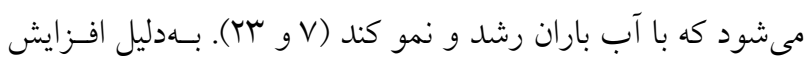

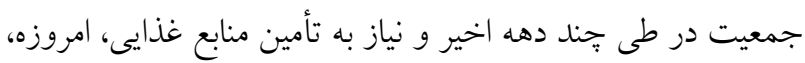

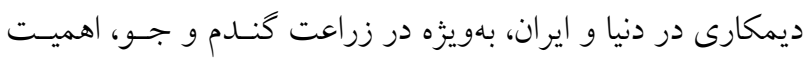

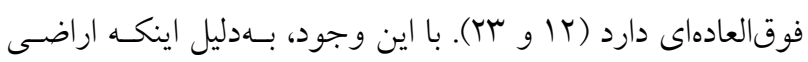

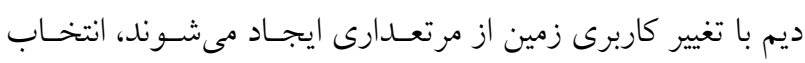

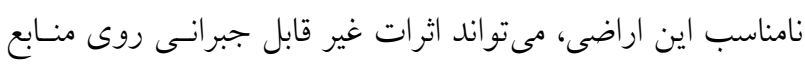

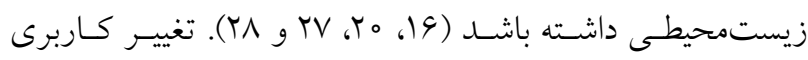

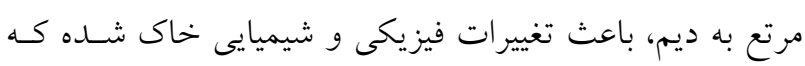

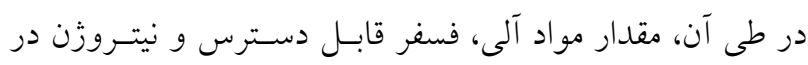

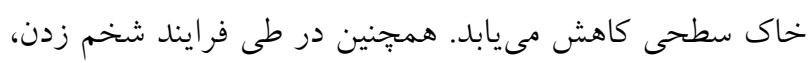

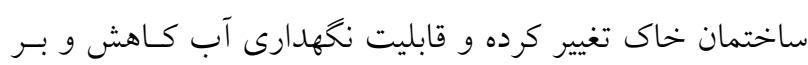

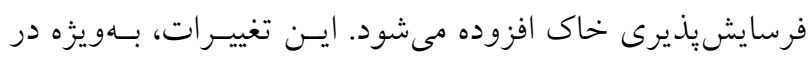

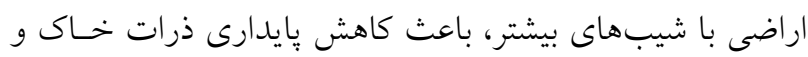
افزايش فرسايشيذيرى خاك در اثـر برخـورد قطرات بـاران و

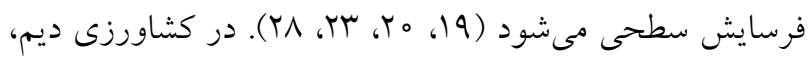

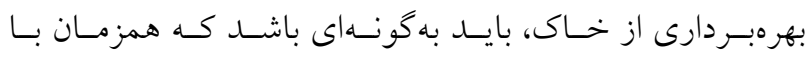

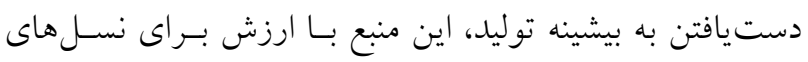

آينده با كيفيت مناسب، باقى بماند (ه و عY).

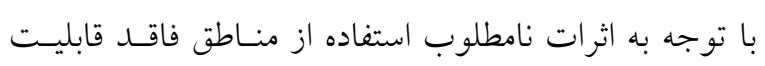
براى يكى كاربرى، بهمنظور دستيابى به توسعه پِايـدار و اسـتفاده

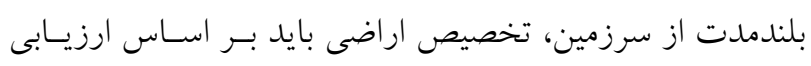

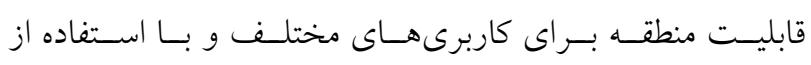

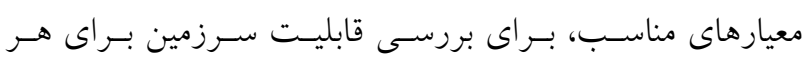

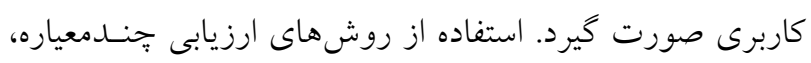

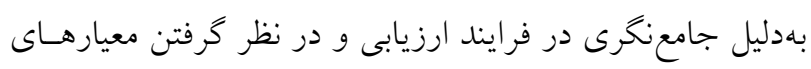

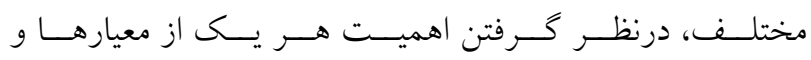

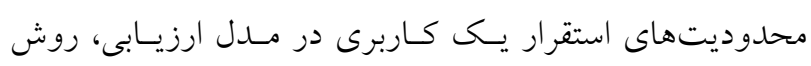

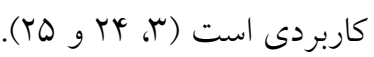

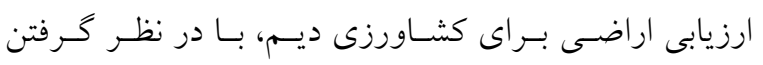

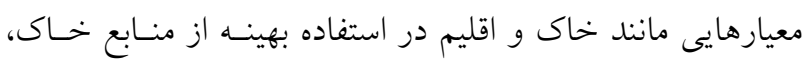




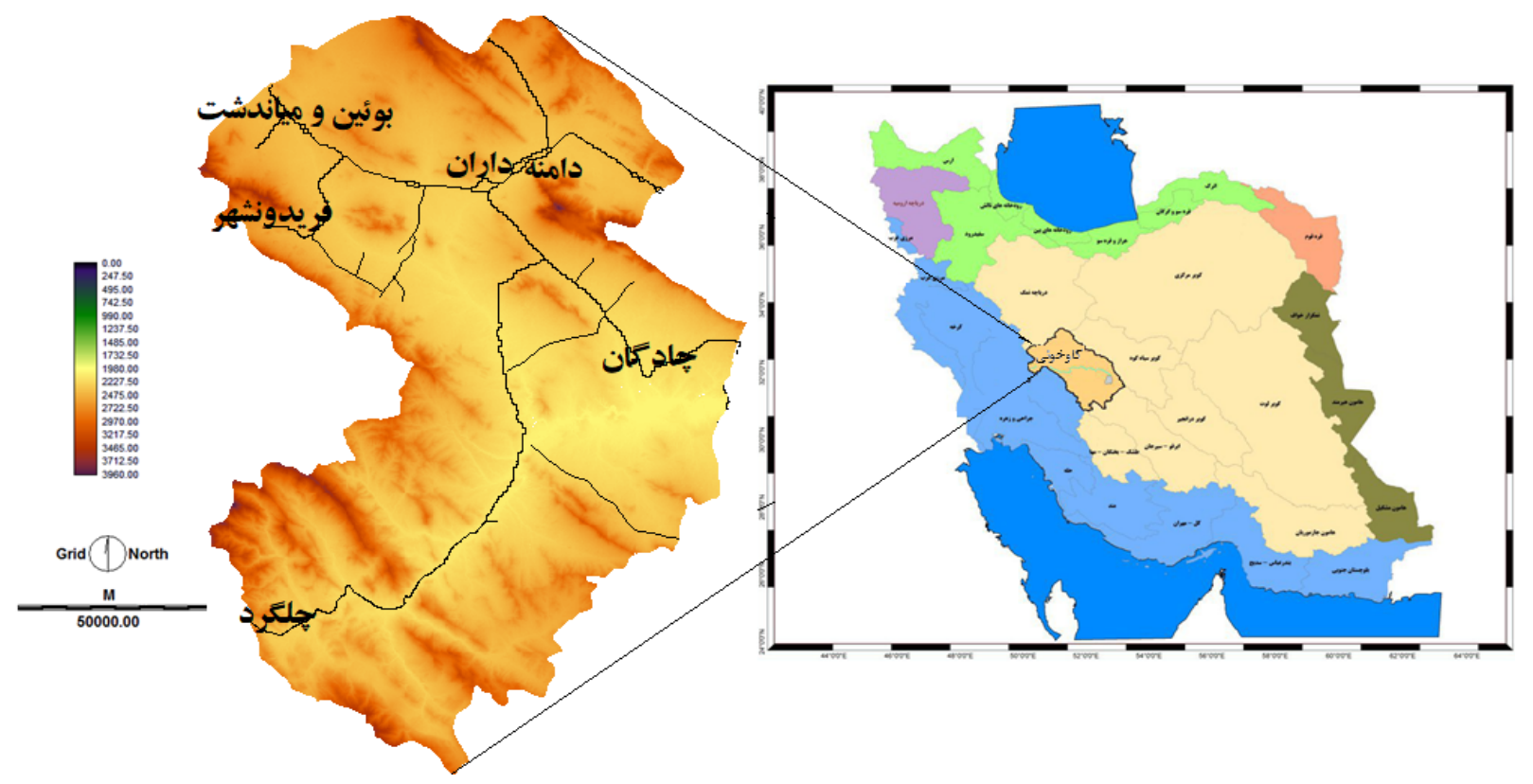

شكل 1. محدوده مطالعه در غرب حوضه كاوخونى (Yr)

دادههاى مورد استفاده

براى شناسايى معيارهاى مناسب ارزيابى قابليت ديمكارى اراضسى، از نظرات اساتيد و خبر گان در بخش كشاورزى و مرتعـدارى و مـرور مطالعات انجام شده مشابه، استفاده و ويايايى برسشـنامهها بـا ضـريب آلفاى كرونباخ محاسبه شد. همبستخى بين معيارها نقشـه معيارهـا از آرشيو مطالعات اكبرى و همكاران (T) با دقت اعلام شده قابل قبول، تهيه شد. نقشه كاربرى و يوشـش اراضسى بــراى سـالهاى IIVD و و هوبا منطقه از مطالعات راهدارى و همكاران (YT)، تهيه شد.

تهيه مدل مفهومى ارزيابى قابليت كثاورزى ديم اراضى يس از تعيين معيارهاى مورد نياز، مدل سلسله مراتبسى ارزيـابى قابليت ديمكارى، با نظر كارشناسان و مرور منابع تهيه شد.

\section{استانداردسازى معيارها و محدوديتها} از آنجايى كه معيارهاى مورد استفاده، داراى واحدهاى متفـاوتى بودند، لازم بود تا بـراى اسـتفاده در مــدل ارزيـابى، همــهـ آنهـا استاندارد شوند. بنابر اين محدوديتهاى ديمكارى (مانند درياجٍه سد) بهصورت بولين و ساير معيارها به روش فازى و با تعيين حدود و توابع فازى بين صفر و يك، استاندارد شدند.
يزّوهش، تعيين مناطق با قابليت بـراى كشـاورزى ديسم در ايسن زير حوضه است. همجنين، بررسى اراضى زيركشت ديم فعلى از نظر قابليت ديمكارى، از ديخر اهداف اين بززوهش است.

مواد و روش ها اين مطالعه در زيرحوضه آبخيز بِلاسـجان بـا وسـعت 999rان هكتار انجام شده است. حداقل ارتفاع منطقـه 190019 و بيشـترين آن هوب متر با اقليمىنيمهسرد و مديترانهاى، ميانخين بلندمدت دما، بين 9 در منطقـه كوهرنـ تـا با در شـرق زيرحوضـه در شهرستان جادگان، در نوسان است. آمار بارندگى بهطور متوسط

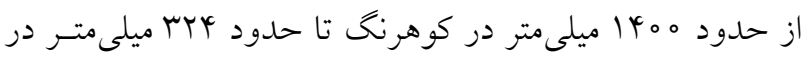
شهرستان جادگان متفاوت است. زيرحوضـه آبخيـز پيلاسـجان، بهدليل داشتن بيشترين بارش در حوضه گاوخونى، بهعنوان منبع آب حوضه آبى كاوخونى اسـت ( (1). كشـاورزى و دامــارى از مهمترين منابع ارتزاق مردم اين منطقه اسـت. بـهدليل بارنــدى مناسب در اين ناحيه، ديمكارى مورد توجه ساكنين قرار كرفتسه است و بيشترين محصولات ديم، شامل گندم و جو است (Y). شكل (1)، موقعيت حوضه آبى گـاوخونى و زيرحوضسه آبخيـز ياسجان را نشان مىدهد. 


\begin{tabular}{|c|c|c|}
\hline محدوده & تعريف & طبقه \\
\hline 1/ & با قابليت خيلى زياد & 1 \\
\hline 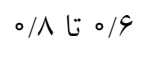 & با قابليت زياد & r \\
\hline 14/4 تا ه & با قابليت متوسط & r \\
\hline لتا & با قابليت كم & $\varphi$ \\
\hline صفر تا ب/ه & با قابليت خيلى كم & 0 \\
\hline صفر & بدون قابليت & 9 \\
\hline
\end{tabular}

يتانسيل ديمكـارى، نقشـه يوشـشهاى اراضـى در سـال 90س1 شامل اراضى ديم و باير مناطق كه مىتوانند به اراضى ديم تبديل شوند روى نقشه مناطق با قابليت ديمكارى زياد و خيلسى زيـاد، قرار داده شد. براى اين منظور، ابتدا، با اعمـال طبقهبنـدى روى نقشه قابليت ديمكارى، اراضى با قابليت ديمكارى زياد و خيلى زياد تفكيك و سبه در محسيط GIS نقشـهـ مراتـع كـم تـراكم، متراكم، جنگل و اراضى ديم روى آنها قرار داده شد.

\section{صحت سنجى مدل تهيه شده}

با فرض انطباق هر طبقـه نقشـه قابليـت ديمكــارى بـا طبقـات مطلوبيت معيارهاى اصلى مورد استفاده در تهيه مدل ديمكـارى، صحتسنجى مدل، با مقايسه طبقات نقشه قابليت اراضى بـراى ديمكارى با طبقـات مطلبوبيـت معيارهـاى اصـلى، انجـام شـــ. بهعنوان مثال، مناطق با قابليت خيلى زياد ديمكارى، بايد از نظر خاى نيز در طبقه با قابليت خيلى زيـاد مطلوبيـت قـرار داشـته باشند و برعكس. بنابراين، در حدود جههـار درصسد منطقـه از نقشه طبقات قابليت ديمكارى اراضسى بــا منــاطق متنـاظر در نقشه طبقات قابليت اراضسى بــراى ديمكــارى در يــنج معيـار اصلى مطالعه (عوامل زيسـتى، فاصـله از فعاليتهـاى انسـانى، اقليم، خاك و شكل زمين) مقايسه شد. معيارها بر اساس جدول (1) - (1) (بقةبندى شدند.

\section{بحث و نتايج}

شكل (Y) و (Y) نقشه كاربرى و يوشش اراضى در سـال IIVD

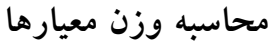

براى ارزيابى اهميت هر يك از معيارها، از روش تحليل سلسله

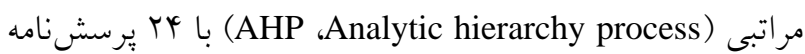
كه بين اسـاتيد كشـاورزى، منـابع طبيعى و كارشناسـان بخـش كشاورزى آشنا با منطقه مطالعه، توزيع شده بود، استفاده شد. بر اساس مدل مفهومى تهيه شده، دادهها بهصورت دو به دو با هـم

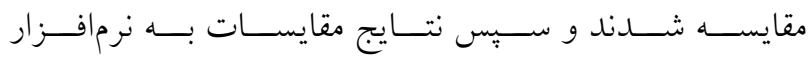
Expert choice

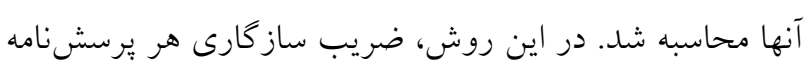

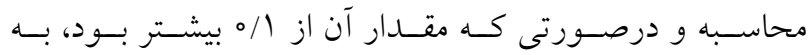
مصاحبهشونده بركشت داده شد و ضمن توضيح بيشـتر دربـاره موضوع و شرايط منطقه مطالعه، از وى درخواست مىشد تـا در مقايسات خود، تجديد نظر كند.

تركيب لايههاى اطلاعاتى و تهيه مدل و نقشه قابليت اراضى براى تركيب معيارها، با در نظركرفتن مدل مفهومى تهيـه شـده، معيارها بهصورت شاخه به شاخه و از بايين بـه بـالا بـا اعمـال وزنهاى محاسبه شده بههمراه محدوديتها، با اسـتفاد از روش تركيبى خطى وزندار در محيط نرمافزار Idrisi-Tiga با يكـديخر تركيب و در نهايت مدل قابليت ديمكارى اراضى تهيـه شـد. بـا اعمال طبقهبندى مجدد بـر اسـاس جـدول (1)، نقشـه قابليـت ديمكارى در شش طبقه تهيه شد. جدول (1) حدود تعيينشده بـراى طبقهبندى مدل نهايى قابليت ديمكارى اراضى را نشان مى دهد. براى بررسى يايدارى مناطق با كاربرى ديم و نيز نـواحى بـا 


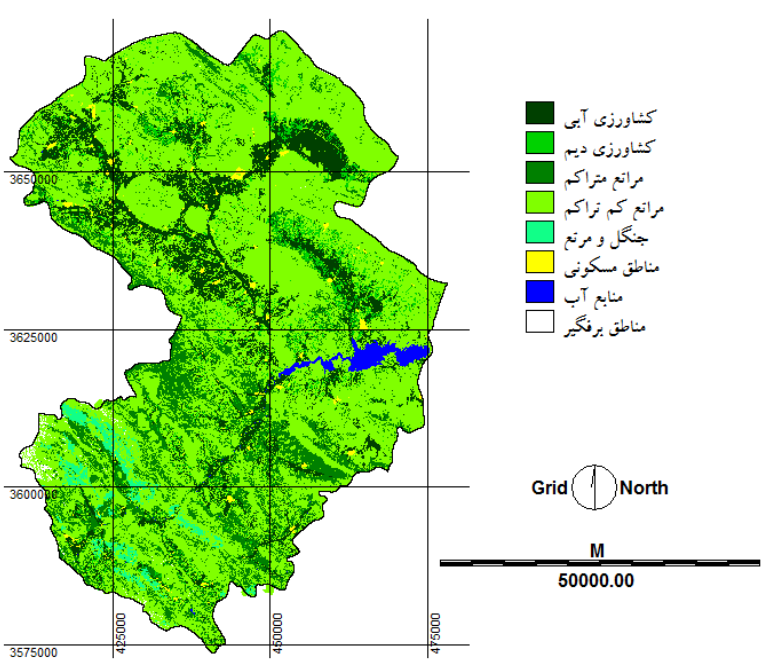

شكل r. نقشه كاربرى و يوشش اراضى در سال هوسا

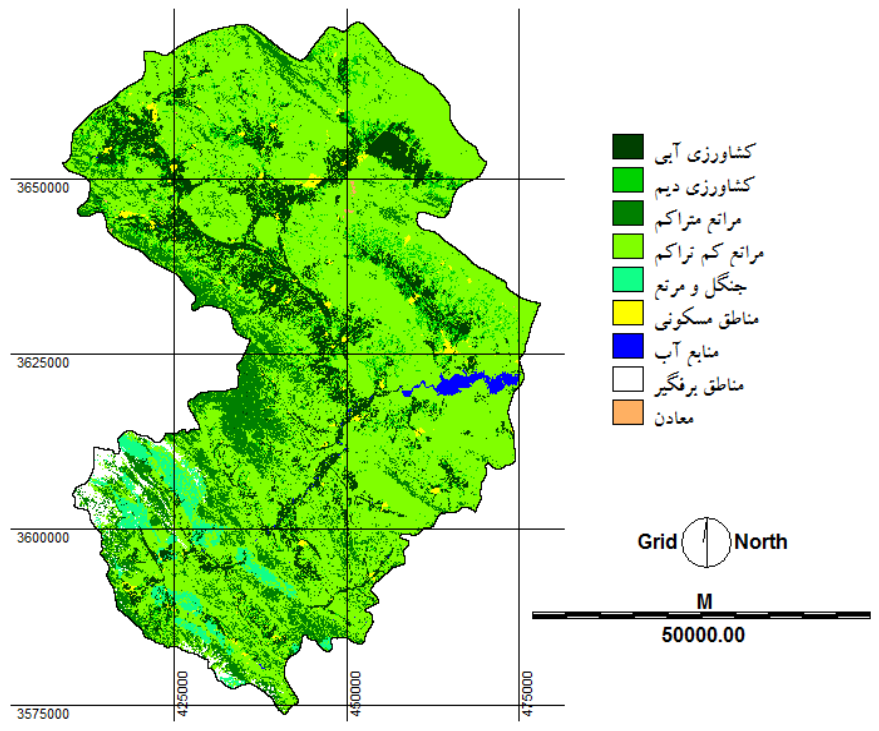

IrVD شكل r. نقشه كاربرى و يوشش اراضى در سال

\begin{tabular}{|c|c|c|c|}
\hline مساحت سال ITVD & مساحت سال 1rq4 & كاربرى و يوشش اراضى & رديف \\
\hline$\Delta \wedge \Delta \mu_{0}$ & $\Delta \wedge \circ Y q$ & كشاورزى آبى & 1 \\
\hline INTOO & TOGAD & كشاورزى ديم & r \\
\hline GMVOO & DTARY & مراتع متر اكم & $r$ \\
\hline TODYQA & ro1991 & مراتع كم تراكم & $r$ \\
\hline$v 490$ & $111 \circ r$ & جنگل و مرتع & $\Delta$ \\
\hline meqn & KTVO & مناطق مسكونى & 4 \\
\hline$p<q 1$ & rqDY & منابع آب & v \\
\hline كمتر از م ه هكتار & rit & معادن و صنايع & $\wedge$ \\
\hline $10 \wedge \mathrm{V}$ & 9114 & مناطق برفكير & 9 \\
\hline \multicolumn{2}{|c|}{ 4) r999 } & جمع & \\
\hline
\end{tabular}

روند تغييرات كاربرى و يوشش هاى اراضى را نشان مى دهد

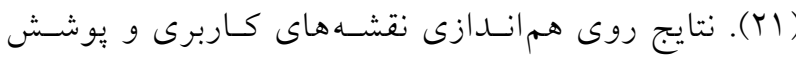

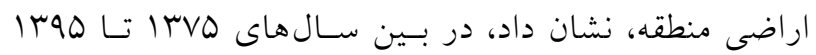

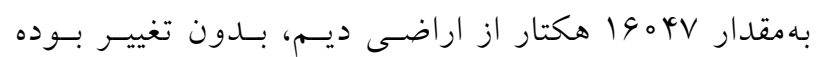
است.

بررسى موقعيت اراضى بــدون تغييـر كـاربرى ديسم، روى نقشه بنج معيار اصلى مـورد اسـتفاده بــراى ارزيـابى قابليـت ديمكارى نيز نشان داد، تمامى اين نواحى در تمام معيارها در
و وبا را نشان مىدهد. نقشهها با ضريب كإِا و صسحت كلى

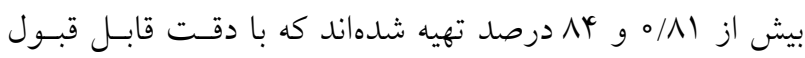

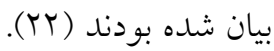
جدول (Y) مساحت هر يكى از طبقـات كـاربرى و يوشـش اراضى در سال هVI ا و هوس ا را نشان مىدهد. براى تعيين اراضـى ديسم بــدون تغييـر از روش مقايسـه

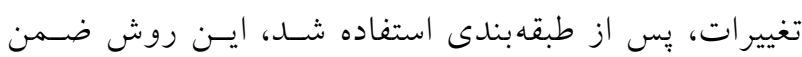

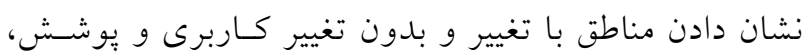


استانداردسازى و وزندهى دادهها

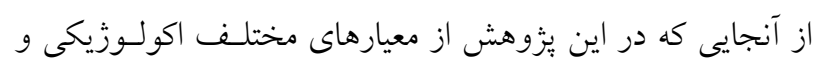
اقتصادى استفاده شد، بنابر اين لازم بود تا براى ايجاد امكـان تلفيـق مهيق

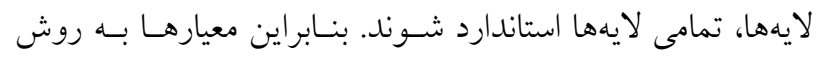

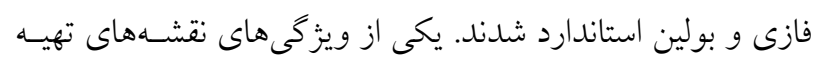

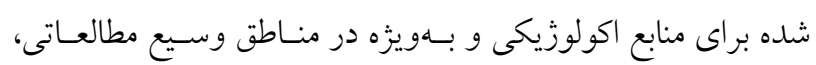

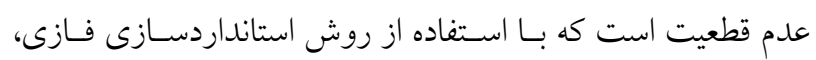

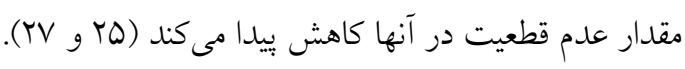

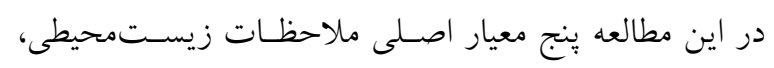

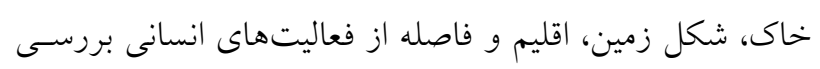

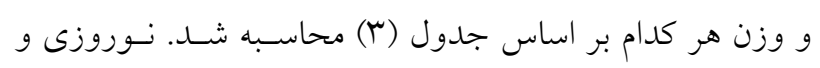

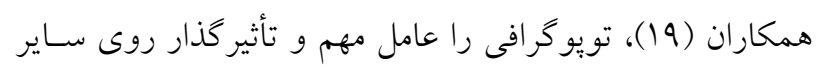

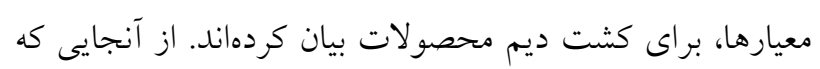

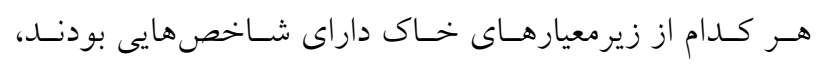
بههمين دليل، وزنهاى زيرمعيار و شاخصهاى خاك درئ در جدول

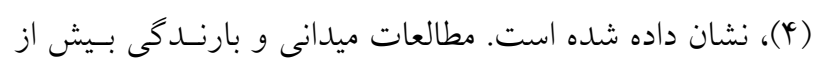

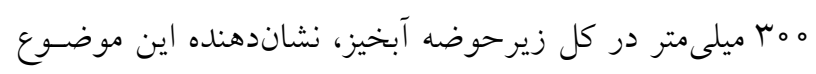

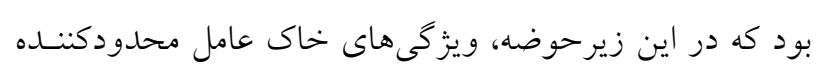

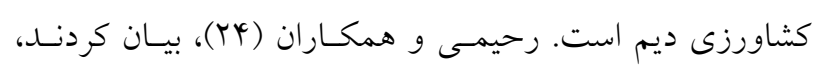

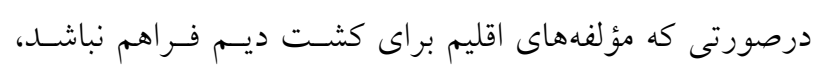

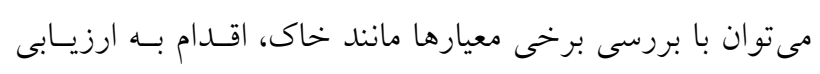

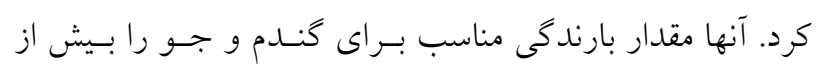
l T TV جدول (r) در ارتباط با اهميت معيارها براى ارزيابى قابليت

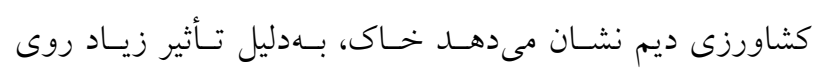

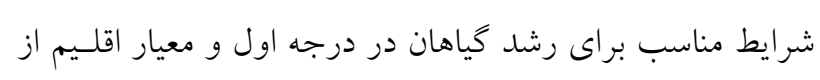

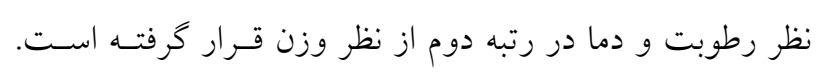

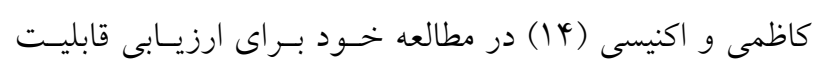

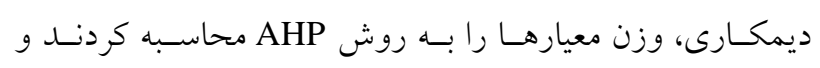

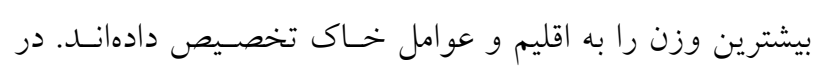

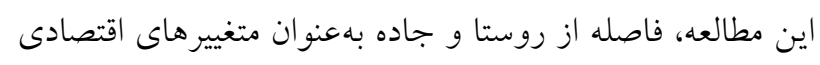
تأثير گذار بر صرفه اقتصادى ديمكارى، در نظر گرفته شده است.
دو طبقه با قابليت زياد و خيلى زياد قرار گرفتهاند. در همسين

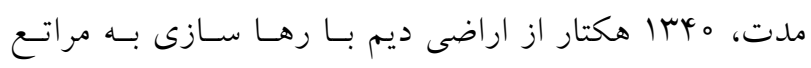

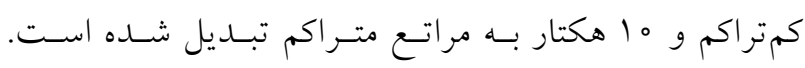

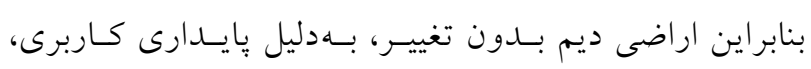

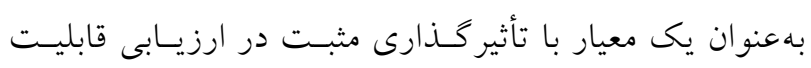

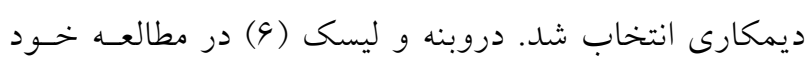

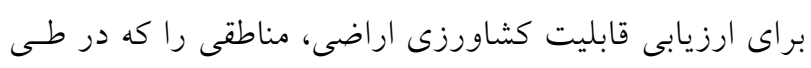

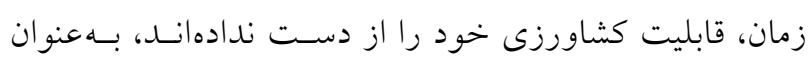

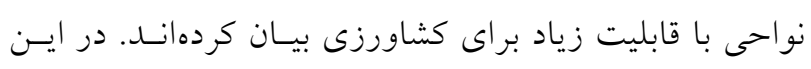
بزوهش براى تعيين معيارها و محدوديت هاى ارزيابى قابليت

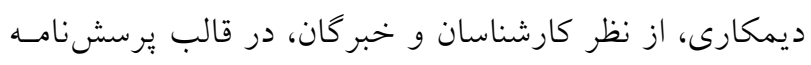

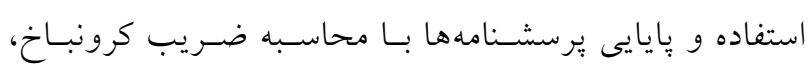

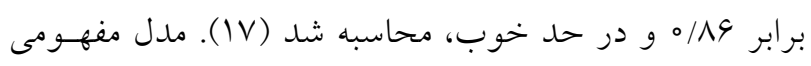

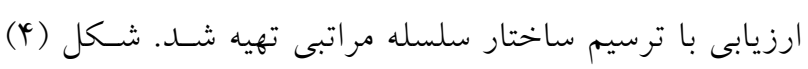

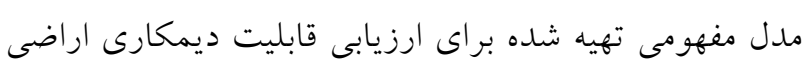

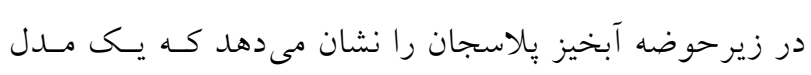
بومى شده براى منطقه مطالعه است.

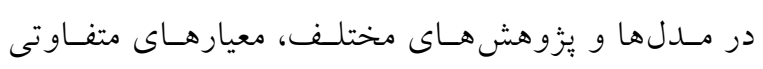

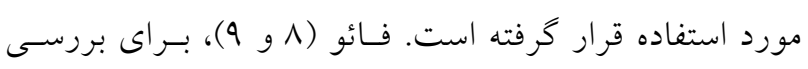

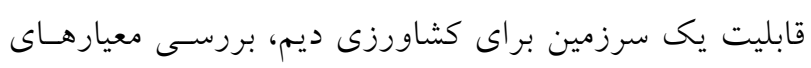

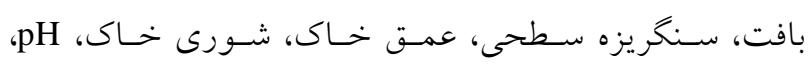

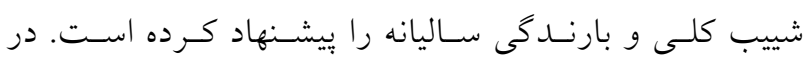

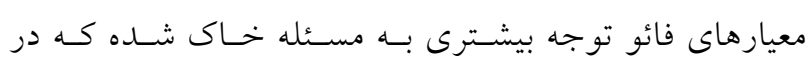

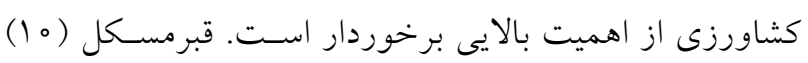

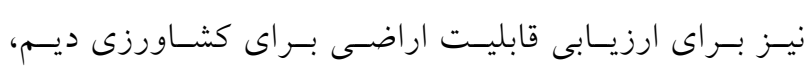

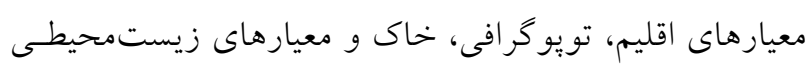

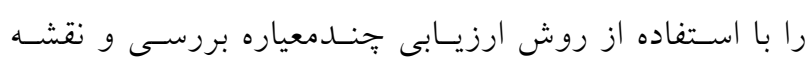

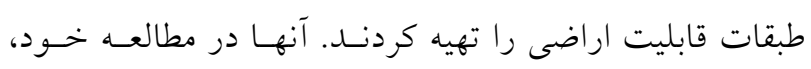

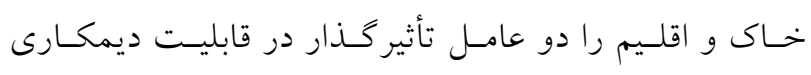

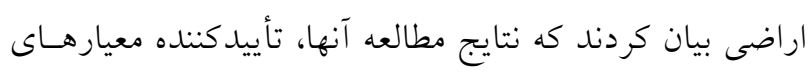

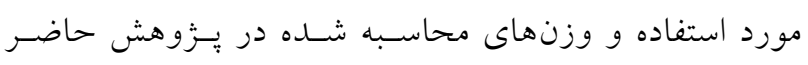
است. 


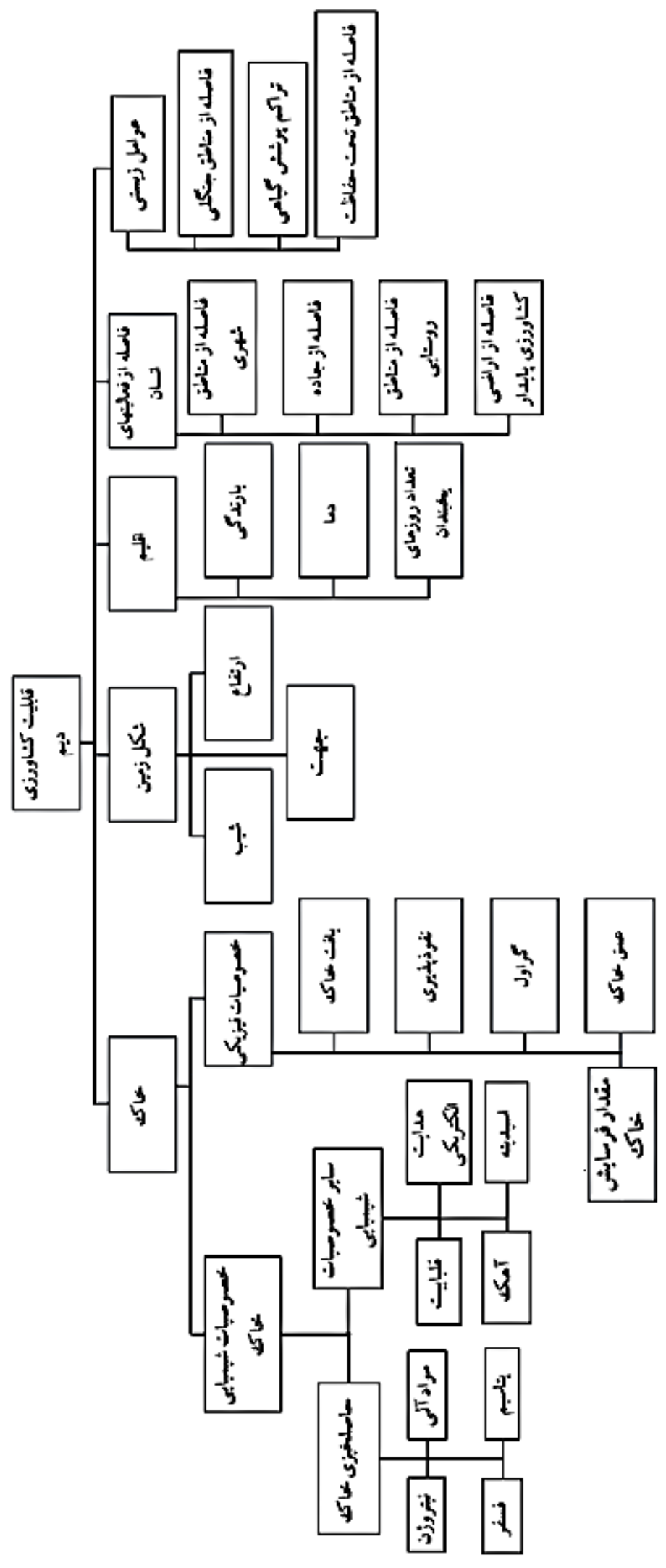

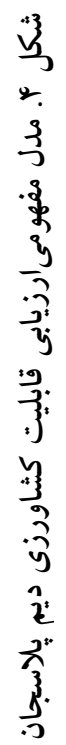




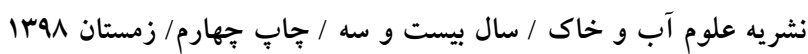

\begin{tabular}{|c|c|c|c|c|c|c|}
\hline وز & شاخص & و & زير معيار & 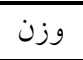 & معيار & رديف \\
\hline- & - & $0 / \mu 1$ & فاصله از مناطق تحت حفاظت & \multirow{3}{*}{$\circ / \circ \wedge$} & \multirow{3}{*}{ عو امل زيستى } & \multirow{3}{*}{1} \\
\hline- & - & 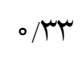 & تراكم يوشش كياهى & & & \\
\hline- & - & $0 / \mu q$ & فاصله از مناطق جنخلى & & & \\
\hline- & - & $0 / 49$ & دما & \multirow{3}{*}{$0 / Y 9$} & \multirow{3}{*}{ 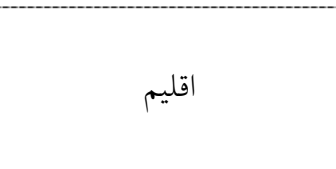 } & \multirow{3}{*}{ r } \\
\hline- & - & $0 / 91$ & بارندگى & & & \\
\hline- & - & $\circ / 14$ & روزهاى يخبندان & & & \\
\hline- & - & $\circ / 0 \circ$ & شيب & \multirow{3}{*}{$\circ / Y Q$} & \multirow{3}{*}{ تويو ر افى } & \multirow{3}{*}{ r } \\
\hline \multirow[t]{2}{*}{-} & - & $0 / \mu r$ & ارتفاع - ار & & & \\
\hline & & $\circ / 1 \wedge$ & جهت & & & \\
\hline- & - & $\circ / 00$ & فاصله از شهر & \multirow{4}{*}{$0 / 14$} & \multirow{4}{*}{ فاصله از فعاليتهاى انسان } & \multirow{4}{*}{ r } \\
\hline- & - & $0 / 41$ & فاصله از روستا & & & \\
\hline- & - & $\circ / \pi \Delta$ & فاصله از جاده & & & \\
\hline- & - & $\circ / 14$ & فاصله از اراضى ديم بِيدار & & & \\
\hline- & - & \multirow{7}{*}{$0 / 4$} & & \multirow{12}{*}{$0 / T V$} & \multirow{12}{*}{ 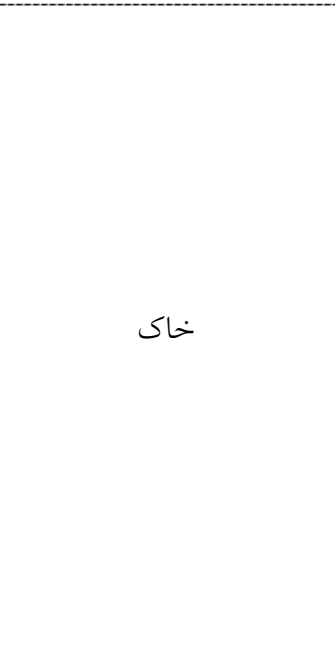 } & \multirow{12}{*}{$\Delta$} \\
\hline- & - & & و ث: هاء & & & \\
\hline- & - & & & & & \\
\hline- & - & & & & & \\
\hline- & - & & & & & \\
\hline - & - & & & & & \\
\hline- & - & & & & & \\
\hline- & - & \multirow{5}{*}{$\circ / \Delta \mathrm{V}$} & \multirow{5}{*}{ ويزگى هاى شيميايى } & & & \\
\hline- & - & & & & & \\
\hline- & - & & & & & \\
\hline- & - & & & & & \\
\hline- & - & & & & & \\
\hline
\end{tabular}

جدول fا. وزنهاى زيرمعيار و شاخص هاى خاك

\begin{tabular}{|c|c|c|c|c|}
\hline وزن & شاخص & وزن & زيرمعيار & معيار \\
\hline$\circ / 09$ & هدايت الكتريكى & $0 / 41$ & ساير ويزگ هاى شيميايى خاى & \multirow{8}{*}{ ويزگگ هاى شيميايى خاى } \\
\hline.$/ 10$ & 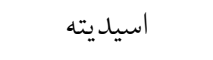 & & & \\
\hline$\circ / \mu$ & ق قلياييت & & & \\
\hline.$/ 4 a$ & آهى & & & \\
\hline $0 / 49$ & مواد آلى & $\circ / 09$ & حاصلخيزى خاى & \\
\hline.$/ 10$ & 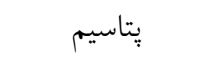 & & & \\
\hline$\mu$ & 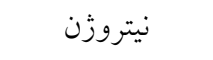 & & & \\
\hline.$/ 19$ & فسفر & & & \\
\hline
\end{tabular}




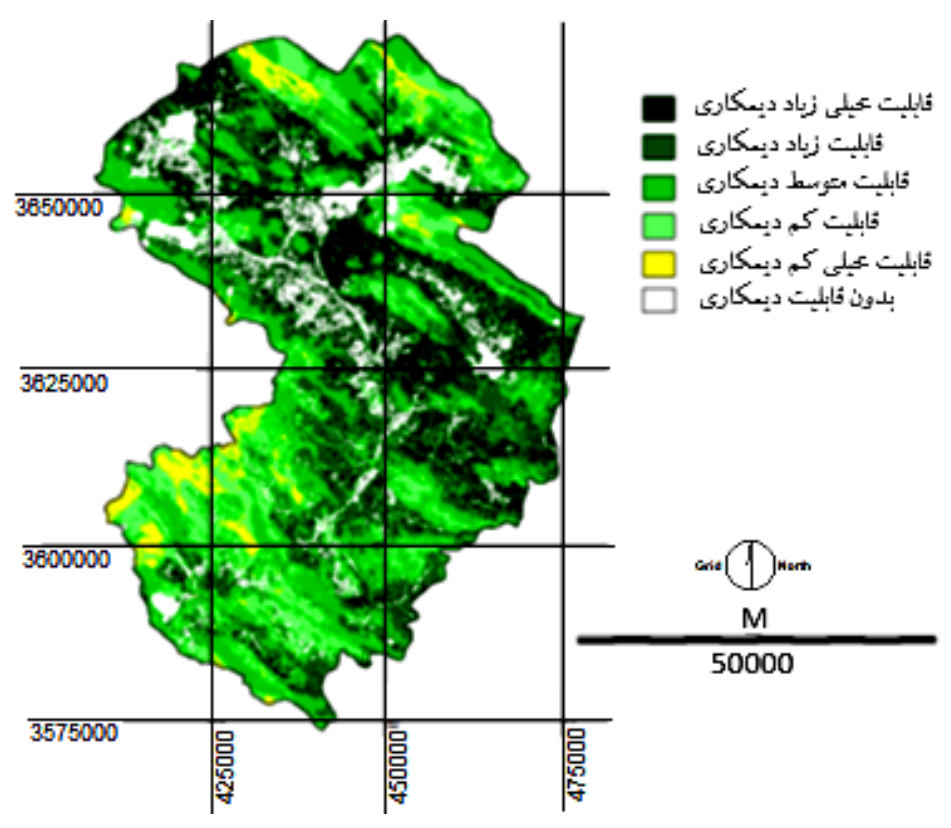

AHP-WLC شكل ه. نقشه قابليت كشاورزى ديم اراضى در مدل

\begin{tabular}{|c|c|c|}
\hline مساحت (هكتار ) & طبقه قابليت & رديف \\
\hline VIOHe & منطقه با قابليت خيلى زياد كشاورزى ديم & 1 \\
\hline 109194 & منطقه با قابليت زياد كشاورزى ديم & r \\
\hline 109001 & منطقه با قابليت متوسط كشاورزى ديم & r \\
\hline OYONI & منطقه با قابليت كم كشاورزى ديم & r \\
\hline viro & منطقه با قابليت خيلى كم كشاورزى ديم & 0 \\
\hline $99 \mu_{0}$ & منطقه بدون قابليت كشاورزى ديم & 9 \\
\hline $41 Y 999$ & جمع & \\
\hline
\end{tabular}

همخوانى طبقات قابليت اراضى با طبقات مطلوبيـت معيارهـاى اصلى، اين انطباق در معيارهاى با وزن كوجّىتر، كمتـر و در معيارهاى با وزن بزرگتر، بيشتر بود. اين مسئله نشـاندهنده

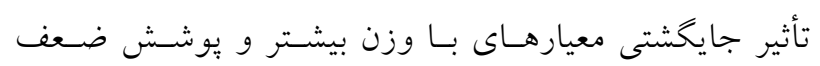
معيارهاى با وزن كمتر در طبقات با قابليت زياد و خيلى زياد

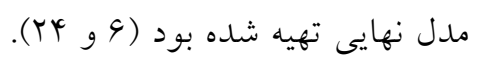
در اين :يزوهش، موقعيت هر يك از بيوششهاى اراضى كـه بهصورت بالقوه امكان تبديل به اراضى ديم را دارند (مرتع و جنگل) و همجنين، اراضى ديم در سال هوبا در طبقات قابليت زيـاد و خيلسى زيـاد ديمكـارى بررسـى شـد. جـدول (9) نتيجـه روى
شـكل (ه) نقشـهـ قابليـت كشـاورزى ديــم اراضـى در منطقـه يالاسجان را نشان مىدهد. جدول (ه) مساحت هريك از طبقات قابليت كشاورزى ديم زير حوضه يِلاسجان بر حسب هكتار را نشان مىدهد. از آنجايى كه براى رسيدن به اهداف اين مطالعه، دقت تهيـهـ نقشه معيارها، پايايى برسش نامسهها و دقـت مقايسـات معيارهـا توسط كارشناسان، ارزيابى شــه بــود، بنـابراين، صـحت نقشـه نهايى قابليت اراضى تهيه شده با محاسبه صحت كلى از طريـق مقايسه نقشه قابليـت ديمكــارى اراضـى بــا طبقـات مطلوبيـت

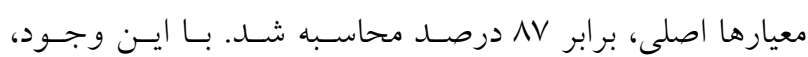




\begin{tabular}{|c|c|c|}
\hline مساحت (هكتار) & وضعيت كاربرى اراضى در نقشه قابليت اراضى & رديف \\
\hline 10099 & كشت در مناطق با قابليت خيلى زياد & 1 \\
\hline $411 \mathrm{~V}$ & كشت در مناطق با قابليت زياد & r \\
\hline MYOI & كشت در مناطق با قابليت متوسط & r \\
\hline IrNT & كشت در مناطق با قابليت كم & $\varphi$ \\
\hline (1) & كشت در مناطق با قابليت خيلى كم & $\Delta$ \\
\hline VIr & كشت در مناطق بدون قابليت & 9 \\
\hline $0 \circ 9 V$ & مراتع متراكم در قابليت خيلى زياد ديم & V \\
\hline 10994 & مراتع كم تراكم در قابليت خيلى زياد ديم & $\wedge$ \\
\hline 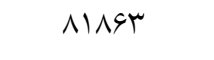 & نواحى جنشلى در قابليت خيلى زياد ديم & 9 \\
\hline$\sqrt{1919}$ & مراتع متراكم در قابليت خيلى زياد ديم & 10 \\
\hline 901 & مراتع كم تراكم در قابليت زياد ديم & 11 \\
\hline r०HV & نواحى جنكلى در قابليت زياد ديم & ir \\
\hline
\end{tabular}

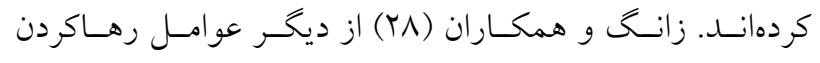

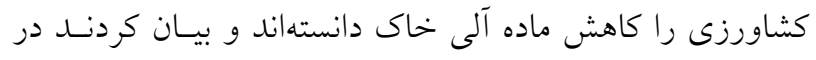
طى عمليات خاكورزى، لايههاى زيرين خاك با مواد آلى كمتر

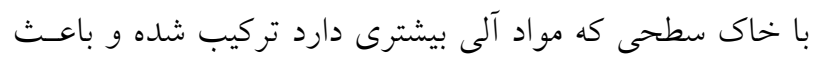

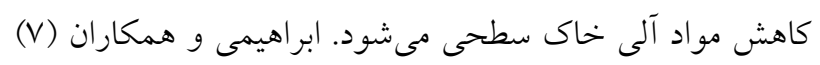

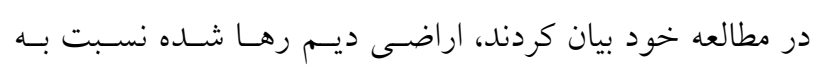

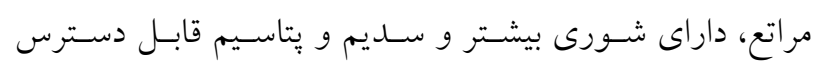

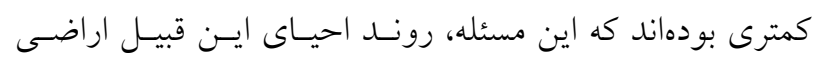

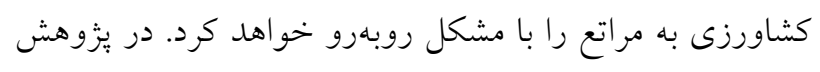

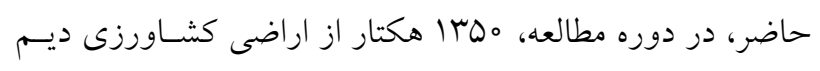

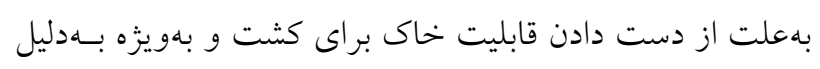

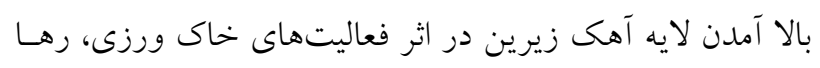

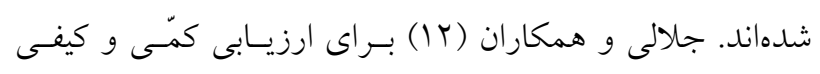

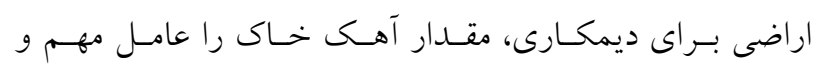

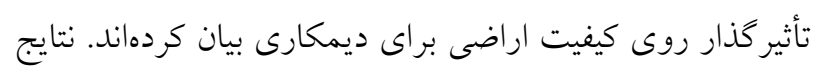

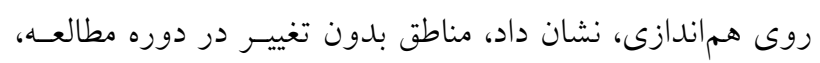
در طبقات با قابليت خيلسى زيساد و زيـاد كشـاورزى ديسم قـرار

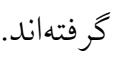

هم اندازى نقشه كاربرى و بوشش اراضى سال هذا1 و دو طبقه اول قابليت ديم اراضى را نشان مىدهد.

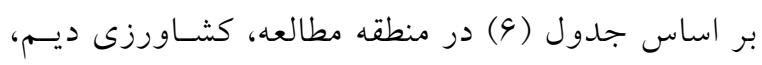
حتى در اراضى با قابليت بسيار كم نيز در حال انجام است.

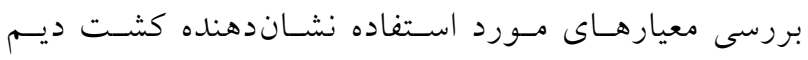

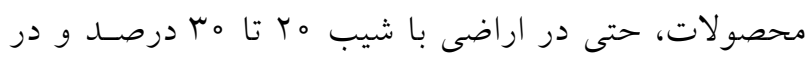

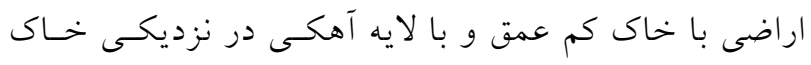

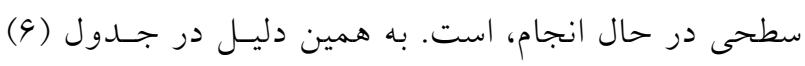

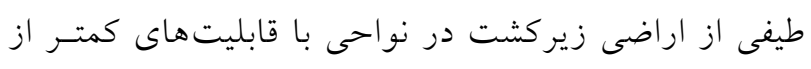

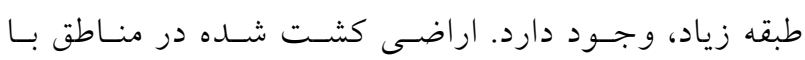

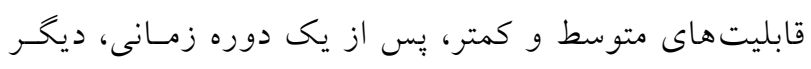

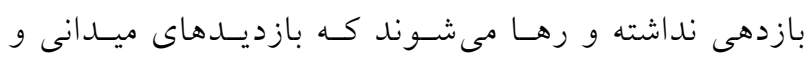

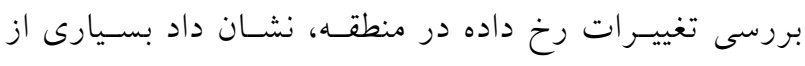

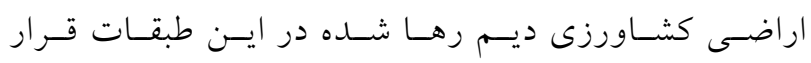

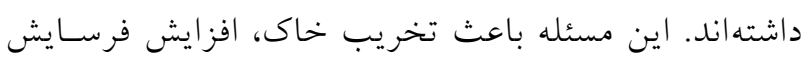

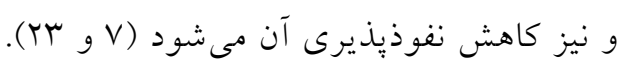

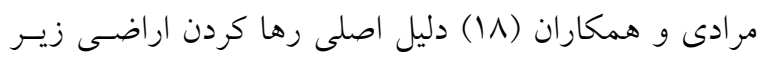
كشت را بهدليل كاهش قابليت آنها بــراى كشـاورزى ديـم بيـان 


$$
\begin{aligned}
& \text { كشت هستند. مدل تهيه شده براى ارزيابى قابليت ديمكـارى در }
\end{aligned}
$$

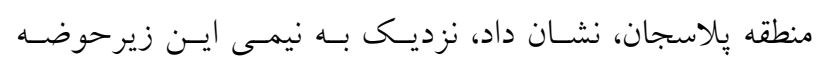

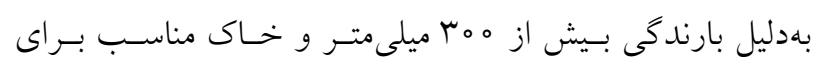

$$
\begin{aligned}
& \text { كشت ديم، داراى قابليت زياد و خيلى زياد براى كشاورزى ديم } \\
& \text { است، اما مسئله مهمى كه بايد به آن توجه كرد ايسن اسـت كـه، }
\end{aligned}
$$

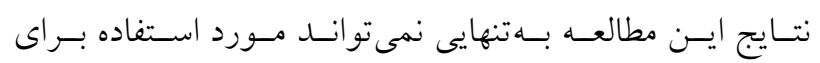

$$
\begin{aligned}
& \text { تصميم كيرى در مورد آينده يك سـرزمين و تخصسيص اراضسى } \\
& \text { براى كشاورزى ديم، قرار گيرد. تخصيص اراضى، بايسـ يسس از } \\
& \text { تعيين نقش يك منطقه در توسعه كـل حوضـه آبخيـز و كشـور }
\end{aligned}
$$

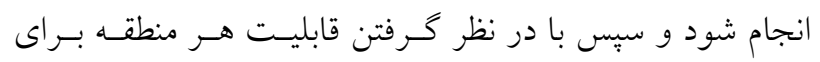

$$
\begin{aligned}
& \text { كاربرىهاى مختلف، در طى فرايند آمايش سـرزمين، تخصسيص }
\end{aligned}
$$

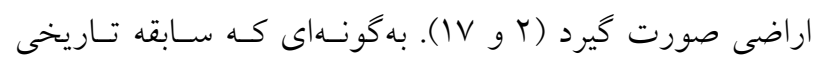

$$
\begin{aligned}
& \text { نشان مىدهد در منطقه يلاسجان، كاركرد اصلى، توليد آب براى } \\
& \text { كل حوضه آبخيز گاوخونى است و بنابراين بار خذارى كاربرىها } \\
& \text { بايد به كونهاى باشد تا بهدليل وجود آب زياد در اين ناحيه، سهم } \\
& \text { ساير بخشهاى حوضه كاوخونى ناديده گرفته نشود. }
\end{aligned}
$$

$$
\begin{aligned}
& \text { در مطالعات مختلف به تأثيرات منفى كشاورزى ديم در اراضسى } \\
& \text { با قابليت كم اشاره شده است كه نتـايج ايسن يـزروهش را تأييــ }
\end{aligned}
$$

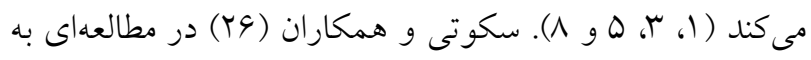

$$
\begin{aligned}
& \text { بررسى تأثير شيب روى ويزگىهاى خاى در كاربرىهاى ديم و }
\end{aligned}
$$

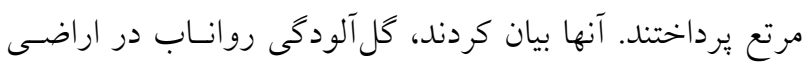

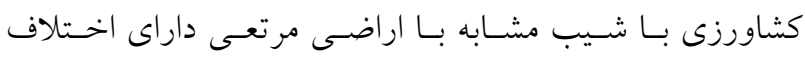

$$
\begin{aligned}
& \text { معنى دارى است. همجينين نشان دادند كه با افزايش شيب، عمـق لق } \\
& \text { خاك در اراضى ديم و مرتع كاهش مىيابد، اما ايسن كـاهش در } \\
& \text { اراضى زيركشت ديم معنى دار است. } \\
& \text { تنيجه كيرى } \\
& \text { نتايج اين مطالعـهـ بــه همـراه بازديـــهاى ميــانى نشـان داد، در }
\end{aligned}
$$

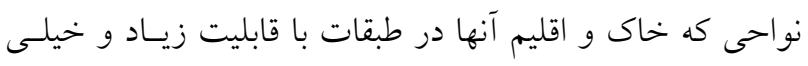

$$
\begin{aligned}
& \text { زياد براى كشاورزى ديم قرار داشـته، كشـت بهصـورت بايسـار } \\
& \text { بوده است و در طى دوره م r ساله مطالعه، اين اراضى با قابليت، } \\
& \text { بههمراه فعاليتهاى خاكورزى، همجنان با كيفيت مناسب زيـر }
\end{aligned}
$$

\section{منابع مورد استفاده}

1. Ahmadi Iilkhchi, A., M. A. Hajabbassi and A. Jalalian. 2003. Effects of converting range to dry-farming land on runoff and soil loss and quality in Dorahan, Chaharmahal \& Bakhtiari Province. Journal of Crop Production and Processing 6(4): 103-115. (In Farsi).

2. Akbari, N. 2015. Isfahan Province Land Use Planning. Environment Section, Isfahn University of Technology. Isfahan. (In Farsi).

3. Aele, A. G., S. S. Demessie, S. Mengistu and A. Melesse. 2016. Landscape dynamics, soils and hydrologicaprocesses in varied climates. Springer 51-52.

4. Ayoubi, SH. and A. Jalalian. 2014. Land Evaluation (for Agriculture and Natural Resource). Isfahan University of Technology Publisher, no: 4, Isfahan. (In Farsi).

5. Bidadi, M., B. Kamkar, O. Abdi and H. Kazemi. 2015. Land suitability analysis on rainfed wheat cropping using geospatial information systems (a case study: Qaresoo Basin). Journal of Agriculture Science and Sustainable Production 25(1): 131-143. (In Farsi).

6. Drobne, S. and A. Lisec. 2009. Multi-attribute Decision analysis in GIS: Weighted linear combination and ordered weighted averaging. Informatica 33: 459-474.

7. Ebrahimi, M., S. Kashani and E. Rouhimoghaddam. 2016. Effect of land use change from rangeland to agricultural land on soil fertility in Taftan region. Journal of Soil and Water Science 26: 31-44. (In Farsi).

8. FAO.1980. Land Evaluation Guidelines for Rainfed Agriculture. World Soil Resources, FAO, No. 52, Rome.

9. FAO. 1983. Guidelines: Land Evaluation for Rainfed Agriculture. FAO Soils Bulletin No. 52, FAO, Rome.

10. Ghebremeskel, L. A. 2003. Land suitability evalution for rainfed agriculture using GIS: tha case study of Weenen natural reserve, KwaZulu-Natal, South Africa. Master thesis, University of Natal, Pietermantzburg, South Africa.

11. Hashemi, M., M. Zarin kafsh and M. Mostashari. 2013. Qualitative evaluation of land suitability on wheat in eqbalieh region of Qazvin state. Research of Agriculture and Natural Resource 3(17): 1-6. (In Farsi).

12. Jalalian, A., M. Amirpour, B. Ghorbani, SH. Ayoubi. 2008. Simulation of runoff, sediment and soil erosion by EUROSEM model in Sulijan Sub- basin, north Karun watershed. Journal of Crop Production and Processing 
11(42): 379-391. (In Farsi).

13. Kabanda, T. 2015. Land capability evolution for crop production using remote sensing, GIS and geo statistics in rietfontein, North West province of South Africa. Journal of Geo UERJ 1981-921.

14. Kazemi, H. and H. Akinci. 2018. A land use suitability model for rainfed farming by Multi-criteria Decision-making Analysis (MCDA) and Geographic Information System (GIS). Ecological Engineering 116: 1-6.

15. Maghami, F., A. R. Karimi, G. H. Haghnia and A. Dourandish, 2013. Evaluation of land use and suitability for rainfed crops in Roin, North Khorasan. Agriculture Ecology 5(2): 143-152. (In Farsi).

16. Moeini, A., L. Sadooghi, S. Mofidi and F. Sharififar. 2016. The Comparison of current land-use proposed of three methods such as Makhdoum, FAO and the Forest, range and Watershed (Case study: Watershed Zanjanrud and QarehPoshtelu). Journal of Natural Environment 69(4): 1129-1143. (In Farsi).

17. Mohammadbeigi, A., N. Mohammadsalehi and M. Aligol. 2015. Validity and reliability of the instruments and types of measurements in health applied researches. Journal of Rafsanjan University of Medical Sciences 13(12): 11531170. (In Farsi).

18. Moradi, A., M. Jafari, H. Arzani and M. Ebrahimi. 2016. Assessment of land use changes into dry land using satellite images and Geographical information system (GIS). Journal of RS and GIS for Natural Resource 7(1): 89100. (In Farsi).

19. Noruzi, M., A. Jalalian, SH. Ayoubi and H. Khademi. 2009. Relationship between wheat yield and terrain attributes in ardal region, Charmahal and Bakhtiari Province. Journal of Water and Soil Science 12(46): 759-770. (In Farsi).

20. Pichand, M. 2017. The effect of grassland conversion to the other agricultural uses on some soil physicochemical properties (case study: watershed basin of Amameh). Journal of Natural Ecosystems of Iran 8(1): 99-122. (In Farsi).

21. Rahdari, V., S. Maleki, K. Afsari and E. Abtin. 2011. Landuse and land cover change detection in hamoun wildlife sanctuary during 1997 to 2010 using remote sensing and GIS. Journal of Remote Sensing and GIS 10(2): 50-61.

22. Rahdari, V., A. R. Soffianian, S. Pourmanafi, R. Mosadeghi and H. Ghaiumi. 2018. A hierarchical approach of hybrid image classification land use and land cover mapping. Geographica Pannonica 22(1): 30-39.

23. Rahmani, H., Y. Asri, M. Ramezani and N. Khorasani. 2016. Effect of rangeland landuse changing into dryland from herbal species diversity viewpoint (case study: rangeland in Dehgolan city, Kordistan). Journal of Environment Science and Technology 18(2): 433-444. (In Farsi).

24. Rahimi, H., A. R. Salman Mahini and H. Kamyab. 2015. Priority of Gorgan's sub-watershed for using rainfed agriculture using Multi-Attribute Decision Making (MADM) and GIS. Journal of Natural Environment 68(3): 401411. (In Farsi).

25. Rajaei, F., A. Esmaili, A. R. Salmanmahiny, M. Delavar, M. Gholipour and M. Bavani. 2017. Prediction the most suitable of agricultural zones in the tajan watershed using Multi Criteria Evaluation (MCE) approach. Town and Country Planning 9(1): 111-127. (In Farsi).

26. Sokoti, R., D. Nikami and N. Ghaemian. 2010. Surviving of slope effect on soil degradation on rangeland and rainfed landuses. In: Proceeding of the $4^{\text {th }}$ Conference of Erosion and deposition. Iran. (In Farsi).

27. Taleai, M., M. Farajzadeh and H. Soleimani. 2014. Land suitability evaluation for cultivation of wheat, based on the FAO Model and Fuzzy-AHP-OWA technique in GIS environment (case study: Miyaneh County). Water and Soil 28 (1): 139-156. (In Farsi).

28. Zhang, L., Z. K. Xei, R. F Zhao and Y. Wang. 2012. The impact of the land use change on the soil organic carbon and labile organic carbon stock in the Longzhong region of Loess platea. Hournal of Aride Land 4 (3): 241-250. 


\title{
Multi- Criteria Evaluation for Land Rain- Fed Agriculture Capability (A Case Study: Plasjan Sub- Basin)
}

\author{
V. Rahdari ${ }^{1 *}$, A. Soffianian ${ }^{2}$, S. Pormanafi ${ }^{2}$, H. Ghayomi Mohammadi ${ }^{3}$, \\ S. Maleki ${ }^{4}$ and V. Pormardan ${ }^{5}$
}

(Received: November 28-2018 ; Accepted: May 21-2019)

\begin{abstract}
In this study, to evaluate the rain- fed land capability in the west of Gavkhooni basin and Plasjn sub- basin, a multi- criteria evaluation method was used. First, by reviewing the literature and expert knowledge, proper data were determined. Criteria and constraint were standardized by Fuzzy and Boolean methods repeatedly and the criteria weights were determined using the analytic hierarchy process. Calculated weights showed that soil and climate criteria with 0.27 and 0.26 had the highest weights among other criteria. Criteria and constraints were combined by considering criteria weights and using the weighted linear combination method; then the rain- fed land capability model was prepared. By re- classing the prepared model, the rain- fed land capability map was produced in 6 capability classes. The results showed that 178430 hectares of the study area was related to very high and high rain- fed capability classes. To determine the rain-fed agriculture sustainability, rain- fed agriculture locations were determined in each land rain- fed capability map. The results showed that 19686 hectares of rain- fed areas were located in high and very high capability and 5999 hectares were the in lower classes.
\end{abstract}

Keywords: Rain- fed agriculture, Land capability, Soil, Water, Weighted linear combination, Plasjan

1. Department of Natural Ecosystems, Hamoun International Wetland Research Institute, University of Zabol, Zabol, Iran.

2. Environment Group, Natural Resource Faculty, Isfahan University of Technology, Isfahan, Iran.

3. Isfahan Agricultural and Natural Resources, Research and Education Center, AREEO, Isfahan, Iran.

4. Environment Group, Natural Resource Faculty, University of Zabol, Zabol, Iran.

5. Agriculture Economic Group, Agriculture Faculty, University of Zabol, Zabol, Iran.

*: Corresponding Author, Email: V.rahdary@gmail.com 